\title{
Bromatological quality of silage from cassava residues: fractionation of proteins and carbohydrates
}

\author{
Qualidade bromatológica da silagem de resíduos da mandioca: fracionamento de \\ proteínas e carboidratos
}

SANTOS, Leones Costa dos ${ }^{1 *}$

https://orcid.org/0000-0002-1104-4880

NASCIMENTO, Willian Gonçalves do ${ }^{2}$

https://orcid.org/0000-0002-4905-3897

AZEVEDO, Marcia Mourão Ramos ${ }^{3}$

https://orcid.org/0000-0001-6894-0670
SILVA, Dulciene Karla de Andrade ${ }^{4}$ https://orcid.org/0000-0002-9024-1507

MACEDO, Italvan Milfont ${ }^{1}$

https://orcid.org/0000-0003-3359-707X

SOARES, Géssica Solanna Calado ${ }^{1}$ https://orcid.org/0000-0002-9066-0576

${ }^{1}$ Universidade Federal Rural de Pernambuco - UFRPE, Rua Dom Manoel de Medeiros, s/n, Dois Irmãos - CEP: 52171-900 - Recife/PE, Brasil

${ }^{2}$ Universidade Federal do Paraná, Setor Palotina, Rua Pioneiro, 2153, CEP: 85950-000 -

Palotina (PR), Brasil

${ }^{3}$ Instituto de biodiversidade e florestas, Campus Santarém - Unidade Tapajós - Av. Vera Paz, s/n. CEP 68035-110- Santarém - PA, Brasil

${ }^{4}$ Universidade Federal do Agreste de Pernambuco, Avenida Bom Pastor, s/n. ${ }^{\circ}$, CEP: 55292-

270, - Boa Vista - Garanhuns/PE, Brasil

*Mail for correspondence: leones.1s10@gmail.com

\section{ABSTRACT}

The objective of this study was to evaluate the quality of silage in the upper third of cassava levels of inclusion of cassava peel, 0,100,200,300,400 g/ kg out based on natural matter (NM) with 60 days of storage on fermentative profile, aerobic stability, chemical composition and protein and carbohydrate fractionation. The material was ensiled in 15 experimental silos, the experimental design adopted was completely randomised, with five treatments and three repetitions. The inclusion of cassava peel in silage from the aerial part of the cassava promoted an increasing linear effect for dry matter content. The contents of crude protein, neutral detergent fibre and acid detergent fibre decreased linearly $(\mathrm{P}<0.05)$ with the inclusion of cassava peel in the silage. The inclusion of the bark promoted an increase in carbohydrate levels. Protein and carbohydrate fractions were influenced by the addition of cassava peel, decreasing the unavailable and/or indigestible fraction (Fraction $\mathrm{C}$ ) of proteins and carbohydrates. The inclusion of cassava peel up to the level of $400 \mathrm{~g} / \mathrm{kg} \mathrm{NM}$ in silage from the aerial part of the cassava improves the fermentation process, aerobic stability and the chemical composition of the silage, and reduces the indigestible fractions of carbohydrates and proteins. 
Keywords: additive, anaerobic fermentation, mandioculture

\section{RESUMO}

Objetivou-se avaliar a qualidade de silagens do terço superior da mandioca acrescida de níveis de inclusão da casca da mandioca, $0,100,200,300,400 \mathrm{~g} / \mathrm{kg}$ com base na materia natural $(\mathrm{MN})$ com 60 dias de armazenamento sobre o padrão fermentativo, a estabilidade aeróbia, a composição bromatológica e o fracionamento de proteínas e de carboidratos. O material foi ensilado em 15 silos experimentais, o delineamento experimental adotado foi o inteiramente casualizado, com cinco tratamentos e três repetições. A inclusão da casca da mandioca na silagem da parte aérea da mandioca promoveu efeito linear crescente para os teores de matéria seca. Os teores da proteína bruta, fibra em detergente neutro e fibra em detergente ácido diminuíram linearmente $(\mathrm{P}<0,05)$ com a inclusão da casca de mandioca na silagem. A inclusão da casca promoveu aumento dos teores de carboidratos. As frações das proteínas e dos carboidratos foram influenciadas pela adição da casca da mandioca na silagem, diminuindo a fração indisponível e/ou indigestível (fração C) das proteínas e dos carboidratos. A inclusão da casca da mandioca até o nível de $400 \mathrm{~g} / \mathrm{kg} \mathrm{MN}$ na ensilagem da parte aérea da mandioca melhora o processo fermentativo, a estabilidade aeróbia e a composição bromatológica das silagens e reduz as frações indigestíveis de carboidratos e de proteínas das silagens.

Palavras-chave: aditivo, fermentação anaeróbia, mandiocultura

\section{INTRODUCTION}

To alleviate the problem of lack of food due to seasonality in the production of ruminants on pasture, silage is proposed with the aim of enhancing the use of forage plants. There are several forage options for conservation in the form of silage, each with its qualitative and productive characteristics. Despite the fact that corn, sorghum and grasses from tropical climates are widely used in the silage process (Lima Júnior et al., 2014; Oliveira et al., 2010), residues from agribusiness have been increasingly used in the feeding of ruminants. In this sense, cassava and its residues may also be a sustainable alternative, both for feeding animals and for processing waste from this activity. In addition to the root and its residues, cassava presents cultural remains or an aerial part composed of leaves and stems (Fluck et al., 2017).

Among the usual means of forage conservation, cassava branch silage appears as a food option for animals, considered a roughage relatively rich in protein and non-structural carbohydrates (Santos \& Santos, 2018). However, in order to achieve maximum use of the food resource, it is necessary to know the nutritional value of the food and the fractions of nutrients that animals can digest and use (Modesto et al., 2004). In view of this, it is possible to observe that studies carried out with silage from the aerial part of the cassava plant are still scarce and insufficient, especially considering the growing need for evaluations that enable more rational use of food. 
The objective of this study was to evaluate silage in the upper third of cassava plus levels of inclusion of cassava peel $(0,100,200,300,400 \mathrm{~g} / \mathrm{kg}$ $\mathrm{NM}$ ) with 60 days of storage on fermentation pattern, stability aerobic, chemical composition and fractionation of carbohydrates and proteins.

\section{MATERIAL AND METHODS}

The experiment was conducted at the Animal Nutrition Laboratory (LANA), located at the Laboratory Support Centre for Research at the Academic Unit of Garanhuns (CENLAG) of the Federal University of Pernambuco (UFRPE).

The evaluated material was silage from the residues of the mandioculture agribusiness composed of leaves from the upper third of the aerial part of the cassava (Manihot esculenta Crantz), with various levels of inclusion of cassava peel (peel, inter-bark, strains and manioc tips). Cassava was harvested at 12 months of age, at Sítio Terra Rica, in the rural area of Garanhuns. The leaves of the upper third of the aerial part were chopped into stationary forage in pieces of approximately $5.0 \mathrm{~cm}$. The peel was dried in the sun until it reached the point where a piece was scratching like chalk; this material being chopped to homogenise the size of the particles. At the time of ensiling, the cassava peel was manually mixed with the upper third of the aerial part of the cassava, based on natural material. The experimental design adopted was completely randomised, with five treatments: $\mathrm{T} 1: \quad 0.0 \mathrm{~g} / \mathrm{kg} ; \mathrm{T} 2: 100.0$ $\mathrm{g} / \mathrm{kg}$; T3: $200.0 \mathrm{~g} / \mathrm{kg}$; T4: $300.0 \mathrm{~g} / \mathrm{kg}$ and T5: $400.0 \mathrm{~g} / \mathrm{kg}$ of inclusion of cassava peel, in three repetitions.

From each sample to be ensiled, $500 \mathrm{~g}$ was removed, packed in paper bags and placed in an oven with forced air ventilation at a temperature of $55^{\circ} \mathrm{C}$ for 72 hours. The chemical-bromatological compositions were obtained according to the recommendations of the AOAC (1990). The NDF and ADF were determined according to Van Soest et al. (1991).

For the production of silage, the samples were stored in experimental silos made of PVC material, $50 \mathrm{~cm}$ high by $10 \mathrm{~cm}$ in diameter and duly identified. The materials were compacted in order to reach a density of $685.0 \mathrm{~kg} / \mathrm{m}^{3}$. Inside each experimental silo, $1.0 \mathrm{~kg}$ of washed and dried sand was used to capture the effluents generated during the ensiling process. After compaction, they were closed with lids equipped with Bunsen valves, to escape gases from fermentation and stored in a covered and ventilated place for 60 days. 
Table 1. Chemical-bromatological composition $(\mathrm{g} / \mathrm{kg} \mathrm{DM})$ of fresh ingredients used for making silage

\begin{tabular}{lllllll}
\hline \multirow{2}{*}{ Variables } & \multicolumn{7}{l}{ Inclusion levels $\left(\mathrm{g} / \mathrm{kg} \mathrm{NM}^{5}\right)$} & \multirow{2}{*}{ Peel } \\
\cline { 2 - 6 } & 0 & 100 & 200 & 300 & 400 & \\
\hline Dry matter (DM) (g/kg NM) & 224.20 & 283.47 & 345.35 & 404.96 & 468.11 & 834.01 \\
Organic matter (OM) & 929.39 & 933.86 & 939.60 & 939.09 & 938.93 & 943.10 \\
Mineral matter (MM) & 70.60 & 66.14 & 60.40 & 60.91 & 61.07 & 56.90 \\
Ethereal extract (EE) & 58.44 & 51.77 & 37.45 & 39.42 & 31.44 & 13.04 \\
NDF $^{1}$ & 402.96 & 511.00 & 330.94 & 446.66 & 421.85 & 310.71 \\
ADF $^{2}$ & 350.13 & 241.47 & 247.48 & 207.68 & 182.09 & 145.07 \\
Cellulose (CEL) & 316.66 & 216.17 & 225.28 & 188.58 & 166.55 & 136.44 \\
Hemicellulose (HEMI) & 52.83 & 269.54 & 83.46 & 238.99 & 239.76 & 165.64 \\
Lignin (LIG) & 33.47 & 25.30 & 22.20 & 19.09 & 15.56 & 8.62 \\
Crude protein (CP) & 237.28 & 195.81 & 162.62 & 138.43 & 122.17 & 43.25 \\
NDIP $^{3}$ & 37.63 & 39.59 & 46.27 & 29.97 & 30.00 & 15.25 \\
ADIP $^{4}$ & 33.17 & 26.55 & 34.85 & 28.59 & 28.85 & 9.20 \\
\hline
\end{tabular}

${ }^{1} \mathrm{NDF}=$ Neutral detergent fibre $;{ }^{2} \mathrm{ADF}=$ Acid detergent fibre $;{ }^{3} \mathrm{NDIP}=$ Neutral detergent insoluble protein; ${ }^{4} \mathrm{ADIP}=$ Acid detergent insoluble protein; ${ }^{5} \mathrm{NM}=$ Natural matter.

At opening, the $\mathrm{pH}$ values were obtained, repeating the measurements every two days until the end of the experimental period of aerobic stability, for each experimental silo. Samples were also collected for the determination of ammoniacal nitrogen (N-NH3) according to Preston (1986).

For evaluation of aerobic stability (AE), approximately $400 \mathrm{~g}$ of each repetition was separated into plastic pots without lids with a capacity of $1 \mathrm{~kg}$. These pots were placed in a room with a controlled temperature $\left(25{ }^{\circ} \mathrm{C}\right)$. The silage temperatures were obtained every 12 hours, for 144 hours, using a thermometer inserted in the centre of the silage mass. Aerobic stability (AE) was calculated as the number of hours observed for the silage, after opening the silo, to increase by $2{ }^{\circ} \mathrm{C}$ in relation to the ambient temperature.

For the analysis of the bromatological composition of the silage, samples were taken and taken to the air circulation oven at $55{ }^{\circ} \mathrm{C}$ for 72 hours, and, subsequently, they were crushed in a mill with a $1 \mathrm{~mm}$ sieve and stored in closed containers.

The chemical-bromatological compositions of the silage were obtained according to the AOAC (1990). The NDF and ADF were determined according to Van Soest et al. (1991). Estimates of truly digestible non-fibrous carbohydrate were determined using NRC equations (2001).

The procedures used for the fractionation of $\mathrm{CP}$ followed the recommendations of Licitra et al. (1996), where Fraction A was obtained by treatment with $10 \%$ trichloroacetic acid (TCA). Then, the nitrogen of the residual material was determined by the macro Kjeldahl method. The difference between total nitrogen and residual nitrogen resulted in that fraction. Fractions B3 and C were determined according to Van Soest et al. (1991). Fractions B1 and B2 were considered as a single fraction and determined by the difference between total $\mathrm{N}$ and Fractions A, B3 and C.

The levels and fractions of carbohydrates were determined according to the equations of Sniffen et al. (1992). 
The data obtained were analysed using the SAS program (2008) for statistical analysis of the results obtained. The significance of the regression coefficients was observed using the $\mathrm{F}$ test, at the level of $5 \%$ and the criteria used to choose the model were based on the significance of the coefficient of determination $\left(\mathrm{r}^{2}\right)$.

\section{RESULTS AND DISCUSSION}

Linear increases in the DM content of the silage were observed as the cassava peel was added, with an estimated increase of $0.580 \mathrm{~g} / \mathrm{kg} \mathrm{NM}$ for each 1 $\mathrm{g} / \mathrm{kg} \mathrm{NM}$ of the peel added to the silage (Table 2). The increases in DM levels were the result of higher concentrations of this nutrient present in the peel, when compared to the aerial part of the cassava (Table 1).

The inclusion of $200 \mathrm{~g} / \mathrm{kg}$ of the bark provided DM content within the ideal range $(30-35 \%)$ for the production of good quality silage (McDonald et al., 1991). However, the other treatments that presented a DM content below or above the range considered ideal, were not affected by the fermentation process, since the $\mathrm{pH}$ of this silage was within the range considered ideal, from 3.8 to 4.2 . This same behaviour was observed by Maciel et al. (2008) who, when working with the inclusion of cassava by-products in grass silage, concluded that the addition of this material reduces the moisture content and can be used to improve the fermentation process and the chemical composition of the silage.

The inclusion of various levels of cassava peel did not influence the levels of OM and MM of silage (Table 2).

The addition of the peel to the aerial part of the cassava resulted in silage with lower levels of $\mathrm{CP}$, with an estimated reduction of $0.333 \mathrm{~g} / \mathrm{kg} \mathrm{DM}$ for each $1 \mathrm{~g} / \mathrm{kg} \mathrm{NM}$ of peel inclusion. This reduction in $\mathrm{CP}$ content in silage can be justified by the low $\mathrm{CP}$ content $(43.25 \mathrm{~g} / \mathrm{kg} \mathrm{DM})$ of the peel in relation to the aerial part of the cassava (237.28 $\mathrm{g} / \mathrm{kg} \mathrm{DM}$ ) (Table 1). 
Table 2. Chemical-bromatological composition $(\mathrm{g} / \mathrm{kg} \mathrm{DM})$ of the silage from the leaves of the upper third of the upper part of the cassava plant with various levels of peel inclusion

\begin{tabular}{|c|c|c|c|c|c|c|c|c|}
\hline \multirow[b]{2}{*}{ Variable $^{1}$} & \multicolumn{5}{|c|}{ Peel inclusion level (g/kg NM) } & \multirow{2}{*}{$\mathrm{SEM}^{2}$} & \multirow{2}{*}{ Regression equation* } & \multirow{2}{*}{$\mathrm{R}^{2}$} \\
\hline & 0 & 100 & 200 & 300 & 400 & & & \\
\hline $\mathrm{DM}$ & 219.67 & 274.80 & 333.66 & 394.93 & 449.82 & 1.296 & $Y=218.494+0.580 X$ & 0.99 \\
\hline OM & 928.69 & 928.33 & 930.41 & 929.70 & 930.28 & 0.841 & NS & - \\
\hline MM & 71.31 & 71.67 & 69.59 & 70.30 & 69.71 & 0.841 & NS & - \\
\hline $\mathrm{CP}$ & 245.66 & 218.62 & 160.64 & 136.28 & 120.48 & 1.809 & $Y=242.873-0.333 X$ & 0.95 \\
\hline NDIP & 39.20 & 39.37 & 32.58 & 27.62 & 32.67 & 0.711 & $Y=39.250-0.025 X$ & 0.61 \\
\hline ADIP & 33.10 & 32.02 & 24.15 & 23.84 & 21.71 & 1.575 & $Y=33.155-0.031 X$ & 0.88 \\
\hline $\mathrm{NDF}$ & 399.63 & 414.72 & 363.10 & 395.86 & 289.99 & 11.922 & $Y=420.286-0.238 X$ & 0.56 \\
\hline $\mathrm{ADF}$ & 322.39 & 313.92 & 290.68 & 244.72 & 235.65 & 8.691 & $Y=330.009-0.243 X$ & 0.94 \\
\hline CEL & 288.54 & 286.90 & 268.95 & 228.25 & 220.27 & 8.638 & $Y=297.623-0.195 X$ & 0.90 \\
\hline HEMI & 75.06 & 113.80 & 72.43 & 153.90 & 56.95 & 14.319 & $Y=72.431+0.428 X-0.106 X^{2}$ & 0.25 \\
\hline LIG & 33.85 & 27.02 & 21.73 & 16.46 & 15.39 & 1.076 & $Y=32.385-0.047 X$ & 0.95 \\
\hline $\mathrm{TCH}$ & 604.32 & 648.10 & 726.79 & 759.06 & 784.76 & 2.884 & $Y=610.238+0.472 X$ & 0.96 \\
\hline NFC & 210.96 & 239.69 & 368.90 & 367.62 & 500.00 & 13.257 & $Y=196.232+0.706 X$ & 0.92 \\
\hline
\end{tabular}

*Significant at $5 \%$ probability by t test.

${ }^{1} \mathrm{DM}=$ Dry matter $(\mathrm{g} / \mathrm{kg} \mathrm{NM}) ; \mathrm{OM}=$ Organic matter; $\mathrm{MM}=$ Mineral matter; $\mathrm{CP}=$ Crude protein; NDIP = Neutral detergent insoluble protein; ADIP = Acid detergent insoluble protein.; $\mathrm{NDF}=$ Neutral detergent fibre; $\mathrm{ADF}=$ Acid detergent fibre; $\mathrm{CEL}=$ Cellulose; HEMI = Hemicellulose; LIG =Lignin; TCH $=$ Total carbohydrates; NFC $=$ Non-fibrous carbohydrates $(\mathrm{g} / \mathrm{kg} \mathrm{TCH}) .{ }^{2} \mathrm{SEM}=$ Standard error of the mean.

The CP contents of the silage varied from 120.48 to $245.66 \mathrm{~g} / \mathrm{kg} \mathrm{DM}$ (Table 2). All silage had a $\mathrm{CP}$ content above $7 \%$, the minimum percentage recommended for effective ruminal microbial fermentation (Van Soest, 1994).

For the PIDN and PIDA contents, linear reductions $(\mathrm{P}<0.05)$ were observed when the cassava peel was included. These reductions in the PIDN and PIDA contents of the silage are attributed to a direct response to the lower PIDN and PIDA contents of the peel when compared to the aerial part of the cassava (Table 1). PIDA contains the protein associated with lignin, tannins and Maillard compounds that are resistant to microbial and enzymatic degradation and is therefore considered unavailable to the animal (Sniffen et al., 1992).

A linear reduction $(\mathrm{P}<0.05)$ of the contents of NDF, ADF and CEL of the silage was observed as the cassava peel was added (Table 2). Such behaviour can be explained by the lower levels of NDF, ADF and CEL of the peel, in relation to the aerial part of the cassava (Table 1). Similar results were obtained by Andrade et al. (2010) and Maciel et al. (2008), who also observed a reduction in the values of NDF, ADF and CEL of elephant grass silage with the addition of cassava by-products. The reduction was explained by the dilution effect caused by the low NDF, ADF and CEL content of the cassava by-products compared to elephant grass. 
It is noteworthy that the reduction in ADF levels is a good indication of improvement in the nutritional value of silage, as there is a negative correlation between ADF levels and food digestibility, that is, the lower the levels of ADF, the greater the digestibility of DM (Van Soest, 1994).

Silage quality can be estimated by several factors, whether chemical or biological, so the reduction in the contents of NDF and ADF with the inclusion of cassava peel may be one of the indicators to be observed together with the other parameters to obtain a good quality silage.

The levels of HEMI in silage were influenced in a quadratic way $(\mathrm{P}<0.05)$ by the levels of bark inclusion, with the highest values of HEMI being verified for the intermediate inclusion levels $(100,200$ and $300 \mathrm{~g} / \mathrm{kg} \mathrm{NM})$ and the lowest values for silage without added bark and with $400 \mathrm{~g} / \mathrm{kg} \mathrm{NM}$ of inclusion (Table 2).

The levels of lignin in silage decreased linearly $(\mathrm{P}<0.05)$ with the addition of cassava peel. As the lignin content in the cassava peel is $24.85 \mathrm{~g} / \mathrm{kg} \mathrm{DM}$ lower than that of the aerial part (Table 1 ), the inclusion of this additive favoured the reduction of this fraction, due to the dilution effect.

According to Ribeiro et al. (2010), the use of additives in silage can promote a decrease of constituents of the cell wall, mainly regarding lignin. This result is important, as this is the main limitation of the degradation of the fibrous fraction of forage.
The inclusion of cassava peel promoted an increasing linear effect, both in the contents of TC and NFC, of silage from the aerial part, being, respectively, $0.472 \mathrm{~g} / \mathrm{kg} \mathrm{DM}$ and $0.706 \mathrm{~g} / \mathrm{kg} \mathrm{DM}$, with an increase of $1 \mathrm{~g} / \mathrm{kg} \mathrm{NM}$ of peel (Table 2).

In relation to protein fractions, it was found that the inclusion of increasing levels of cassava peel to silage from the aerial part caused a linear reduction in the contents of Fraction A (non-protein nitrogen) (Table 3). Thus, for each unit of cassava peel added to the silage from the aerial part, there was a reduction of $0.142 \mathrm{~g}$ of $\mathrm{CP} / \mathrm{kg} \mathrm{DM}$ of this fraction.

It was also observed that Fraction A (immediate availability in the rumen) of the evaluated silage, presented the highest values in relation to the variables $\mathrm{B} 1+\mathrm{B} 2, \mathrm{~B} 3$ and $\mathrm{C}$. With anaerobic fermentation of the ensiled mass, part of the protein can be degraded into simpler compounds, such as non-protein nitrogen, due to proteolysis (Pires et al., 2009).

Fractions B1 and B2 were considered as a single fraction $(\mathrm{B} 1+\mathrm{B} 2)$ and refer to true soluble and insoluble proteins. For Fraction B1 + B2, a linear decreasing effect $(\mathrm{P}<0.05)$ was observed with the inclusion of cassava peel (Table 3 ), and for each $1 \mathrm{~g} / \mathrm{kg} \mathrm{NM}$ of the peel added to the ensiled material, there was a reduction of $0.166 \mathrm{~g}$ of $\mathrm{CP} / \mathrm{kg} \mathrm{DM}$ of this fraction. According to these results, it is evident that the addition of cassava peel to forage from the aerial part of the cassava reduces the concentration of Fraction $\mathrm{B} 1+\mathrm{B} 2$, giving the silage a lower protein value. 
Table 3. Fractions of proteins ( $\mathrm{g}$ of $\mathrm{CP} / \mathrm{kg} \mathrm{DM}$ ) from silage of the leaves of the upper third of the aerial part of the cassava with various levels of peel inclusion

\begin{tabular}{lllllllll}
\hline \multirow{2}{*}{ Variable $^{1}$} & \multicolumn{9}{l}{ Peel inclusion level (g/kg NM) } & \multirow{2}{*}{${ }^{2}$ SEM } & Regression equation* & \multirow{2}{*}{$\mathrm{R}^{2}$} \\
\cline { 2 - 7 } & 0 & 100 & 200 & 300 & 400 & & & \\
\hline $\mathrm{A}$ & 115.83 & 103.81 & 82.97 & 68.92 & 62.24 & 3.559 & $\mathrm{Y}=115.167-0.142 \mathrm{X}$ & 0.97 \\
$\mathrm{~B} 1+\mathrm{B} 2$ & 90.63 & 75.44 & 45.09 & 39.73 & 25.57 & 3.007 & $\mathrm{Y}=88.457-0.166 \mathrm{X}$ & 0.95 \\
$\mathrm{~B} 3$ & 6.10 & 7.36 & 8.43 & 3.79 & 10.96 & 1.415 & $\mathrm{NS}$ & \\
$\mathrm{C}$ & 33.10 & 32.02 & 24.15 & 23.84 & 21.71 & 1.575 & $\mathrm{Y}=33.155-0.031 \mathrm{X}$ & 0.88 \\
\hline
\end{tabular}

* Significant at $5 \%$ probability by $\mathrm{t}$ test.

${ }^{1} \mathrm{~A}=$ Non-protein nitrogen; $\mathrm{B} 1=$ fraction rapidly degraded in the rumen; $\mathrm{B} 2=$ fraction of intermediate degradation; $\mathrm{B} 3=$ fraction of slow degradation in the rumen.; $\mathrm{C}=$ fraction unavailable. ${ }^{2} \mathrm{SEM}=$ Standard error of the mean.

The levels of inclusion of cassava peel did not influence $(\mathrm{P}>0.05)$ the protein Fraction B3 (Table 3). This fraction occurs in association with the cell wall and is considered to be a digestible fraction, but of slow degradation in the rumen.

There was a linear reduction $(\mathrm{P}<0.05)$ of $\mathrm{C}$ fractions of silage proteins as cassava peel was added. For each $1 \mathrm{~g} / \mathrm{kg}$ NM of cassava peel added, there was a reduction of $0.031 \mathrm{~g}$ of $\mathrm{CP} / \mathrm{kg} \mathrm{DM}$. This fraction corresponds to nitrogen insoluble in acid detergent, which is linked to lignin and therefore, highly resistant to microbial enzymes in the rumen and indigestible in the gastrointestinal tract of the ruminant animal. In this sense, the inclusion of cassava peel is beneficial to silage, especially by reducing Fraction C. This fact can be attributed to the decrease in PIDA contents as increasing levels of cassava peel were added to the ensiled material (Table 1).

As for the fractionation of carbohydrates, linear increases in Fractions A + B1 (high rate of ruminal degradation) of silage were observed with the levels of inclusion of cassava peel. The starch present in the shell, possibly, was responsible for the elevations observed in Fraction A + B1 since this fraction in the silage without the addition of the shell represented only $26 \%$ of the total carbohydrates.

The silage with inclusion of 300 and $400 \mathrm{~g} / \mathrm{kg} \mathrm{NM}$ of cassava peel showed the highest values for Fraction A + B1 in relation to Fractions B2 and C. Foods with high Fraction $\mathrm{A}+\mathrm{B} 1$ are considered good energy sources for ruminal microorganisms using NFC. However, for better use of this fraction for the growth of ruminal microorganisms, it is necessary to include protein sources of rapid to medium degradation in the rumen.

The addition of cassava peel to silage reduced $(\mathrm{P}<0.05)$ the content of Fraction B2 (Table 4), a digestible portion of the plant cell wall of slow ruminal degradation. The lower cellulose values of cassava peel before ensiling (136.44 $\mathrm{g} / \mathrm{kg} \quad \mathrm{DM})$, was possibly reflected in the reductions of the B2 fractions of the silage with peel inclusion, since the aerial part of the cassava presented, at the time of silage, higher cellulose content $(316.66 \mathrm{~g} / \mathrm{kg}$ DM). The observed reduction was 0.629 $\mathrm{g} / \mathrm{kg} \mathrm{TCH}$ for each $1 \mathrm{~g} / \mathrm{kg} \mathrm{NM}$ of added cassava peel.

A linear reduction $(\mathrm{P}<0.05)$ was observed for Fraction $\mathrm{C}$ when cassava peel was added $(\mathrm{P}<0.05)$. For each 1 
$\mathrm{g} / \mathrm{kg}$ of cassava peel inclusion, a reduction of $0.223 \mathrm{~g} / \mathrm{kg} \mathrm{TCH}$ was obtained in the values of Fraction $\mathrm{C}$. The lower lignin content in the peel, certainly, reduced the levels of Fraction $\mathrm{C}(\mathrm{g} / \mathrm{kg} \mathrm{TCH})$ of silage with shell inclusion, in order to positively interfere in the availability of the constituents of the cell wall. The lower levels of Fraction $\mathrm{C}$ can cause greater digestibility of carbohydrates present in the cell wall and consequently, higher consumption of DM (Van Soest, 1994).

Table 4. Fractions of carbohydrates from silage of the leaves of the upper third of the upper part of the cassava with various levels of peel inclusion

\begin{tabular}{|c|c|c|c|c|c|c|c|c|}
\hline \multirow{2}{*}{ Variable $^{1}$} & \multicolumn{5}{|c|}{ Peel inclusion level (g/kg NM) } & \multirow{2}{*}{${ }^{2} \mathrm{SEM}$} & \multirow{2}{*}{$\begin{array}{l}\text { Regression } \\
\text { equation * }\end{array}$} & \multirow{2}{*}{$\mathrm{R}^{2}$} \\
\hline & 0 & 100 & 200 & 300 & 400 & & & \\
\hline $\mathrm{A}+\mathrm{B} 1$ & 270.31 & 321.71 & 473.60 & 463.02 & 625.74 & 17.934 & $Y=260.44+0.852 X$ & 0.92 \\
\hline B2 & 595.20 & 578.21 & 454.65 & 484.88 & 327.21 & 16.645 & $\mathrm{Y}=613.89-0.629 \mathrm{X}$ & 0.84 \\
\hline $\mathrm{C}$ & 134.49 & 100.08 & 71.75 & 52.10 & 47.05 & 3.865 & $Y=125.66-0.223 X$ & 0.93 \\
\hline
\end{tabular}

*Significant at $5 \%$ probability by $\mathrm{t}$ test.

${ }^{1} \mathrm{~g} / \mathrm{kg}$ total carbohydrates; $\mathrm{A}=$ soluble sugars; $\mathrm{B} 1$ = starch and pectin; $\mathrm{B} 2=$ digestible fraction of the cell wall; $\mathrm{C}=$ Indigestible fraction of the cell wall. ${ }^{2} \mathrm{SEM}=$ standard error of the mean.

The addition of cassava peel promoted a linear increase $(\mathrm{P}<0.05)$ in the aerobic stability of the cassava silage (Table 5).

The highest AE was observed in silage with inclusion of $400 \mathrm{~g} / \mathrm{kg}$ of $\mathrm{NM}$ of cassava peel, which remained stable for up to 144 hours. The higher AE presented may be associated with the lower content of protein and/or dry matter present in this silage, which can inhibit or hinder the development of deteriorating aerobic microorganisms (Barbosa et al., 2011; Rabelo et al., 2012).

There was an increase in $\mathrm{pH}$ over time, with an average between 4.11 and 4.69. This variation in $\mathrm{pH}$ during the period of exposure to air is possibly an indication that the silage was being deteriorated by the action of aerobic microorganisms. For the zero level of cassava peel inclusion, less stability was observed $(84 \mathrm{~h})$, as an increase in $\mathrm{pH}$ over time was observed. The loss of aerobic stability of silage is usually manifested by an increase in temperature and a change in $\mathrm{pH}$. According to Jobim et al. (2007), the main residual substrates used are acids, ethanol and soluble sugars, resulting in increased $\mathrm{pH}$, reduced digestibility and reduced energy content. The increase in $\mathrm{pH}$ after exposure of silage to air, the decrease in content of soluble carbohydrates and the low concentration of lactic acid are important indicators of deterioration of the ensiled mass. 
Table 5. Average values of aerobic stability (EA), buffer capacity (CT), ammoniacal nitrogen $\left(\mathrm{N}-\mathrm{NH}_{3}\right)$ and $\mathrm{pH}$ of silage from the leaves of the upper third of the upper part of the cassava with various levels of peel inclusion

\begin{tabular}{|c|c|c|c|c|c|c|c|c|}
\hline \multirow{2}{*}{ Variable } & \multicolumn{5}{|c|}{ Peel inclusion level (g/kg NM) } & \multirow{2}{*}{${ }^{2} \mathrm{SEM}$} & \multirow{2}{*}{ Regression equation* } & \multirow{2}{*}{$\mathrm{R}^{2}$} \\
\hline & 0 & 100 & 200 & 300 & 400 & & & \\
\hline EA $(h)^{1}$ & 84.00 & 108.00 & 124.00 & 124.00 & 144.00 & 17.435 & $Y=89.600+0.136 X$ & 0.93 \\
\hline $\mathrm{CT}^{2}$ & 67.09 & 55.56 & 51.90 & 38.56 & 39.13 & 2.256 & $Y=65.034-0.073 X$ & 0.92 \\
\hline $\mathrm{N}-\mathrm{NH}_{3}(\% \mathrm{NT})$ & 20.00 & 29.50 & 51.00 & 56.83 & 53.50 & 0.398 & $Y=17.395+0.212 X-0.029 X^{2}$ & 0.94 \\
\hline $\mathrm{pH} \mathrm{Oh}$ & 3.98 & 4.02 & 4.02 & 4.06 & 4.04 & 0.004 & $Y=3.977+0.004 X-0.00006 X^{2}$ & 0.93 \\
\hline $\mathrm{pH} 48 \mathrm{~h}$ & 3.98 & 3.96 & 3.96 & 3.99 & 3.97 & 0.018 & NS & - \\
\hline pH 96h & 4.68 & 4.24 & 4.11 & 4.14 & 4.04 & 0.082 & $Y=4.634-0.038 X+0.0006 X^{2}$ & 0.92 \\
\hline pH 144h & 6.11 & 5.78 & 5.18 & 5.21 & 4.38 & 0.238 & $\mathrm{Y}=6.136-0.004 \mathrm{X}$ & 0.93 \\
\hline $\mathrm{pH}$ medium & 4.69 & 4.50 & 4.32 & 4.35 & 4.11 & 0.139 & $\mathrm{Y}=4.652-0.001 \mathrm{X}$ & 0.92 \\
\hline
\end{tabular}

* Significant at $5 \%$ probability by $\mathrm{t}$ test.

${ }^{1} \mathrm{EA}(\mathrm{h})=$ Aerobic stability; ${ }^{2} \mathrm{CT}=$ Buffer capacity $(\mathrm{e} . \mathrm{mg} \mathrm{HCl} / 100 \mathrm{~g} \mathrm{DM}) .{ }^{2} \mathrm{SEM}=$ Standard error of the mean.

As cassava peel inclusion in the silage increased, the buffer capacity showed a decreasing linear behaviour. The levels with 300 and $400 \mathrm{~g} / \mathrm{kg} \mathrm{NM}$ showed lower values of buffer capacity, possibly influenced by the content of soluble carbohydrates that contributes to good silage quality. On the other hand, the silage that did not receive the addition of cassava peel showed a greater buffering capacity. This result probably occurred due to protein and the products of its degradation, as protein content can be a negative element in silage due to its buffering power, which reduces the speed of the $\mathrm{pH}$ drop. According to Jobim et al. (2007), when the plant has a high TC, the $\mathrm{pH}$ lowering speed is slow and the losses in the ensiling process are higher, reducing the silage quality. Thus, the greater the buffering capacity, the greater the amount of lactic acid formed so that the $\mathrm{pH}$ reaches levels that are inhibitory to the action of microorganisms harmful to the silage quality.

In relation to N-NH3, a quadratic effect $(\mathrm{P}<0.05)$ of the addition of cassava peel was detected in silage from the aerial part, the values varied between 20.00 and $56.83 \%$ NT, with a lower value for the treatment without bark inclusion. According to Monteiro et al. (2011), N-NH3 is the product of fermentation of bacteria of the genus Clostridium and its content should not exceed $11-12 \%$ of total nitrogen in well-preserved silage. In the present work, despite the high concentrations of $\mathrm{N}-\mathrm{NH} 3 / \mathrm{NT}$ in the silage, the $\mathrm{pH}$ values (3.98 to 4.06) suggest the occurrence of intense acid-lactic fermentation in these materials, indicating adequate fermentation.

The silage with 200,300 and $400 \mathrm{~g} / \mathrm{kg}$ NM, until 96 hours, remained within the ideal $\mathrm{pH}$ range of 3.8 and 4.2 (McDonald et al., 1991) indicative of quality silage. This behaviour may possibly be related to the DM content, since the treatments with higher DM contents showed a good fermentative pattern.

The inclusion of cassava peel up to the level of $400 \mathrm{~g} / \mathrm{kg} \mathrm{NM}$ in silage from the aerial part of the cassava improves the fermentation process, aerobic stability 
and chemical composition of the silage, and reduces the indigestible fractions of

\section{ACKNOWLEDGEMENTS}

This work was carried out with the support of the Coordination for the Improvement of Higher Education Personnel - Brazil (CAPES) -

\section{REFERENCES}

ANDRADE, I.V.O.; PIRES, A.J.V.; CARVALHO, G.G.P.de.; VELOSO, C.M.; BONOMO, P. Perdas, características fermentativas e valor nutritivo da silagem de capim-elefante contendo subprodutos agrícolas.

Revista Brasileira de Zootecnia, v.39, n.12, p.2578-2588, 2010.

ASSOCIATION OF OFFICIAL ANALYTICAL CHEMISTS - AOAC. Official methods of analysis. 15.ed. Arlington: AOAC International, 1990.

BARBOSA, L.A.; REZENDE, A.V.; RABELO, C.H.S.; RABELO, F.H.S.; NOGUEIRA, D.A. Estabilidade aeróbia de silagens de milho e soja exclusivas ou associadas. Ars Veterinária, v.27, n.4, p.255-262, 2011.

FLUCK. A.C; PARZIANELLO. R.R.; MAEDA, E.M.; PIRAN FILHO, F.A; COSTA, O.A.D.; SIMIONATTO, M. Caracterização química da silagem de rama de cultivares de mandioca com ou sem pré-secagem. Boletim de Industria Animal, Nova Odessa,v.74, n.3, p.176-181, 2017.

JOBIM, C.C.; NUSSIO, L.G.; REIS, R.A.; SCHMIDT, P. Avanços metodológicos na avaliação da qualidade da forragem conservada. carbohydrates and proteins.

Financing Code 001. The Foundation for the Support of Science and Technology of the State of Pernambuco - FACEPE for supporting the first author's dissertation project.

Revista Brasileira de Zootecnia, v.36, p.101-119, 2007. Suplemento especial.

LICITRA, G.; HERNANDEZ, T.M.; VAN SOEST, P.J. Standardization of procedures for nitrogen fractionation of ruminant feed. Animal Feed Science Technology, v.57, n.4, p.347-358, 1996.

LIMA JÚNIOR, D.M.; RANGEL, A.H.N.; URBANO, S.A.; OLIVEIRA, J.P.F.; MACIEL, M. do V. Silagem de gramíneas tropicais não-graníferas. Agropecuária Científica no SemiÁrido, v.10, n.2, p.01-11, 2014.

MACIEL, R.P.; NEIVA, J.N.M.; OLIVEIRA, R.C.; ARAÚJO, V.L.de.; LÔBO, R.N.B. Características fermentativas e químicas de silagens de capim -elefante contendo subproduto da mandioca. Revista Ciência

Agronômica, v.39, n.1, p.142-147, 2008.

McDONALD, P.; HENDERSON, A.R.; HERON, S.J.E. The biochemistry of silage. 2.ed. Marlow: Chalcombe, 1991. $340 \mathrm{p}$.

MODESTO, E.C.; SANTOS, G.T.; VILELA, D.; SILVA, D.C.; FAUSTINO, J.O. JOBIM, C.C.; 
DETMAN, E.; ZAMBOM, M.A.; MARQUES, J.A. Caracterização químico- bromatológica da silagem do terço superior da rama de mandioca. Acta Scientiarum Animal Sciences, v.26, n.1, p.37-146, 2004.

MONTEIRO, I.J.G.; ABREU, J.G. de.; CABRAL, L.da.S.; RIBEIRO, M.D.; REIS, R.H.P.dos. Silagem de capimelefante aditivada com produtos alternativos. Acta Scientiarum. Animal Sciences, v.33, n.4, p.347-352, 2011.

NATIONAL RESEARCH COUNCIL NRC. Nutrient requirements of dairy cattle. Washington: D.C. National Academy of Science, 2001. 381p.

OLIVEIRA, L.B.; PIRES, A.J.V.; VIANA. A.E.S.; MATSUMOTO. S.N.; CARVALHO, G.G.P. de.; RIBEIRO, L.S.O. Produtividade, composição química e características agronômicas de diferentes forrageiras. Revista Brasileira de Zootecnia, v.39, n.12, p.2604-2610, 2010.

RIBEIRO, L.S.O.; PIRES, A.J.V.; CARVALHO, G.G.P. de; SANTOS, A.B. dos; FERREIRA, A.R.; BONOMO, P.; SILVA, F.F da. Composição química e perdas fermentativas de silagem de cana-deaçúcar tratada com ureia ou hidróxido de sódio. Revista Brasileira de Zootecnia, v.39, n.9, p.1911-1918, 2010.

SANTOS, M.A.; SANTOS, B.R.C. Silagem da palma forrageira consorciada com resíduos da mandioca e bagaço da cana de açúcar: Revisão.

PUBVET v.12, n.11, a218, p.1-8, Nov., 2018.
PIRES, A.J.V.; CARVALHO, G.G.P. de.; GARCIA, G.; CARVALHO JUNIOR, J.N. de.; RIBEIRO, L.S.O.; CHAGAS, D.M.T. Fracionamento de carboidrato e proteína de silagem de capim-elefante com casca de café, farelo de cacau ou farelo de mandioca. Revista Brasileira de Zootecnia, v.38, n.3, p.422-427, 2009.

PRESTON, T.R. Better utilization of crop residues and by products in animal feeding: research guidelines. A practical manual for research workers. Rome: FAO, 1986. 154p.

RABELO, C.H.S.; REZENDE, A.V.de; NOGUEIRA, D.A.; RABELO, F.H.S.; SENEDESE, S.S.; VIEIRA, P. de F.; BARBOSA, L. de Á.; CARVALHO, A. Perdas fermentativas e estabilidade aeróbia de silagens de milho inoculadas com bactérias ácido-láticas em diferentes estádios de maturidade. Revista Brasileira de Saúde e Produção Animal, v.13, n.3, p.656668, 2012.

SNIFFEN, C.J.; O'CONNOR, J.D.; VAN SOEST, P.J.; FOX, D.G.; RUSSEL, J.B. A net carbohydrate and protein system for evaluating cattle diets: II. Carbohydrate and protein availability. Journal Animal Science, v.70, n.10, p.3562-3577, 1992.

STATISTICAL ANALYSIS SYSTEM - SAS. SAS/STAT Software Version 9.2. Cary: SAS Institute Inc., 2008.

VAN SOEST, P.J.; ROBERTSON, J.B.; LEWIS, B.A. Methods for dietary fiber, neutral detergent fiber, and nonstarch polysaccharides in relation to animal 
nutrition. In: Symposium Carbohydrate Methodology, Metabolism, and

VAN SOEST, P.J. Nutritional ecology Nutritional Implications in Dairy Cattle. of the ruminant. 2. New York: Cornell Journal Dairy Science, v.74, n.10, University Press, 1994. 476p. p.3583-3597, 1991. 